\title{
Pathogenesis of heart block in a fatal case of dermatomyositis
}

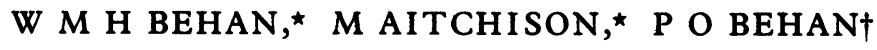 \\ From the Departments of ${ }^{*}$ Pathology and $\nmid$ Neurology, Glasgow University
}

SUMMARY Approximately $70 \%$ of patients with dermatomyositis have evidence of cardiac damage; in one third of cases this affects principally or solely the conduction tissue. In infants similar histological lesions have been associated with a maternal autoantibody, anti-Ro, that crosses the placenta and produces congenital heart block. Anti-Ro antibody was detected in a fatal case of dermatomyositis with lesions of the conduction system.

Dermatomyositis (polymyositis, when there is no associated rash) is an inflammatory myopathy of unknown aetiology that affects the heart in about $70 \%$ of cases. Heart failure is the third leading cause of death in the disorder. ${ }^{1}$ In one third of those affected the conduction system is principally or solely damaged. ${ }^{12}$ A specific maternal autoantibody, anti-Ro, that crosses the placenta and damages the fetal heart produces the same heart injury in infants. ${ }^{3}$ Because there are numerous immunological abnormalities in dermatomyositis, including the presence of various autoantibodies, ${ }^{4}$ we examined the serum of a case of dermatomyositis with heart block for anti-Ro antibody. This autoantibody was detected on two occasions before she died of cardiac failure.

\section{Case report}

\section{HISTORY}

A 59 year old housewife was admitted to hospital with a five week history of rash, muscle pain, and severe weakness. She was otherwise healthy. A right mastectomy for carcinoma had been carried out seven years before. She had a florid, heliotrope rash over both upper eyelids and an erythematous maculopapular rash on each hand. The shoulder and pelvic muscles were very tender, movement was painful, and power was reduced to $3 / 5$ in all proximal muscles. Normal sensation and reflexes were present. The pulse was regular ( 90 beats $/ \mathrm{min}$ ), blood pressure was $140 / 80 \mathrm{~mm} \mathrm{Hg}$, and an aortic ejection systolic murmur was present.

Requests for reprints to Dr W M H Behan, Department of Pathology, Western Infirmary, Dumbarton Road, Glasgow G11 6NT.

\section{INVESTIGATIONS}

The erythrocyte sedimentation rate was $11 \mathrm{~mm} / \mathrm{h}$, creatine kinase concentration was 2248 IU/l (normal < $100 \mathrm{IU} / 1$ ), lactic dehydrogenase 1144 IU/1 (normal range $240-525 \mathrm{IU} / 1)$, aspartate aminotransferase $178 \mathrm{IU} / 1$ (normal range $12-42 \mathrm{IU} / 1$ ), and alanine aminotransferase $47 \mathrm{IU} / 1$ (normal range 10-50 IU/1). The blood urea concentration was raised $(17 \cdot 1 \mathrm{mmol} / 1$, normal range $2 \cdot 5-6.6 \mathrm{mmol} / 1)$. Other routine tests were normal.

Electrocardiography showed sinus rhythm with right bundle branch block and associated right axis deviation (fig 1 ). The chest $x$ ray was normal. Electromyography and muscle biopsy were diagnostic of active dermatomyositis.

\section{CLINICAL COURSE}

Prednisolone $(80 \mathrm{mg} /$ day) was given. The muscle weakness remained, serum creatine kinase activity increased to $3360 \mathrm{IU} / 1$, and a right axillary vein thrombosis developed. Severe congestive cardiac failure then developed and on the fifth day she had a cardiorespiratory arrest. She had assisted ventilation for three days but severe central and peripheral oedema unresponsive to diuretic or inotropic treatment occurred and she died 12 days after admission.

\section{NECROPSY FINDINGS}

All muscles, especially the pectorals and deltoids, were pale and flabby with occasional yellow streaks. The heart weighed $380 \mathrm{~g}$ and had normal chambers and valves except for moderately thickened but not stenotic aortic cusps. The coronary arteries were free from any atheromatous narrowing. She also had a bronchopneumonia and a thyroid adenoma but no 




Fig 1 Electrocardiogram on admission showing right bundle branch block.

recurrent breast carcinoma.

\section{MICROSCOPIC EXAMINATION}

Representative skeletal and cardiac muscle samples and skin were taken and either frozen in liquid nitrogen or fixed in formalin. The heart was sectioned as described ${ }^{5}$ to investigate the conduction system.

Skeletal muscles-There was focal but widespread muscle damage with a sparse inflammatory infiltrate and numerous regenerating fibres in all the muscles examined.

Heart-There was a generalised mild myocarditis with foci of segmental necrosis and tiny clusters of lymphocytes and macrophages. The chief damage, however, was in the conduction system, where the right bundle branch showed large areas of complete replacement by fibrous tissue, interspersed with foci of mononuclear inflammatory cells. In addition, both the sinoatrial node and the atrioventricular node (fig 2) showed severe focal fibrosis and loss of Purkinje fibres with infiltrates of mononuclear cells. The bundle of $\mathrm{His}$ and the left bundle branch were normal. There was no evidence of ischaemic damage.

\section{IMMUNOLOGICAL INVESTIGATIONS}

Tests for antibodies to the extractable nuclear antigens (Ro, La, Sm, and RNP) were carried out by counter immunoelectrophoresis ${ }^{6}$ on serum stored at $-20^{\circ}$ that was decomplemented, with an extract of human spleen as the source of the antigens, before testing.

Lymphocyte subsets in the peripheral blood were analysed by a fluorescence activated cell sorter
(FACS IV) and monoclonal antibodies (Ortho Pharmaceutical Corporation and Becton Dickinson). ${ }^{78}$ Sections of skeletal and myocardial muscle were cut $(4 \mu \mathrm{m})$. These were examined by a standard direct immunofluorescence technique for deposited immunoglobulins and complement and we used the patient's serum in a standard indirect immunofluorescent method to detect any localisation of antiRo antibody. Sections of normal heart and skeletal muscle were used as controls. The lymphocyte subpopulations in cardiac and skeletal tissue were counted by an immunoperoxidase histochemical method with Becton Dickinson leucocyte markers. ${ }^{9}$

\section{IMMUNOLOGICAL FINDINGS}

The patient's serum was strongly positive for antiRo antibody. Its immunological identity with a known positive anti-Ro antiserum obtained from the Center for Disease Control, Atlanta, USA, was demonstrated and it was shown by immunoelectrophoresis to be an immunoglobulin G. No other nuclear or organ specific antibodies were found. Serum complement and immunoglobulin concentrations were normal. The peripheral blood lymphocyte results were: T3 (total) lymphocytes $71 \%$ (normal mean (SD) 75 (2)); T4 (helper) lymphocytes $45 \%$ (49(2)); T8 (suppressor/cytotoxic lymphocytes) $15 \%$ (25(2)); Leu 12 (B lymphocytes) $16 \%$ (12(2)), and Leu 7 (K/NK lymphocytes) $7 \%$ (8(3)). The T4:T8 ratio was 3:1 $(2 \cdot 1(0 \cdot 1))$. The results indicated a severe decrease in suppressor cells and this was confirmed by the functional suppressor assay $^{8}$ which showed a $30 \%$ decrease in activity 




Fig 2 Section of atrioventricular node showing partial fibrosis. Haematoxylin and eosin.

compared with a normal healthy control.

Non-specific deposition of IgG was noted in necrotic myocardial, Purkinje, and skeletal muscle fibres. On direct immunofluorescence the anti-Ro antibody produced bright, coarsely granular, intracytoplasmic staining of myocardial, Purkinje, and skeletal muscle fibres. Conduction tissue did not stain differently from the other types of muscle.

In the skeletal and cardiac inflammatory lesions that we examined macrophages formed $50 \%$ of the inflammatory cells in skeletal muscle and $30 \%$ of those in the myocardium, while $\mathrm{T}$ lymphocytes made up $30 \%$ of inflammatory cells in muscle and $60 \%$ of those in the myocardium. B lymphocytes accounted for $20 \%$ and $10 \%$ respectively, no $\mathrm{K}$ cells were found in either tissue, and the helper and suppressor:cytotoxic ratios were 4:1 (skeletal muscle) and 3:1 (myocardium).

\section{Discussion}

This patient had featues typical of dermatomyositis and she developed myocarditis with severe inflammation and fibrosis of the conduction system. She died of cardiac failure. An electrocardiogram showed right bundle branch block but at necropsy we found widespread damage to both the sinoatrial and atrioventricular nodes together with mild focal myocardial inflammation. We detected a specific autoantibody, anti-Ro, in her serum on two occasions and we suggest that this antibody had a pathogenetic effect on her heart tissue.

There is very good evidence that anti-Ro antibody is involved in the lesions of congenital heart block ${ }^{3}$ : it is found in more than $80 \%$ of mothers and affected infants, it is usually the only-autoantibody found in both, it disappears from the infant's serum before six months of age, and, most importantly, maternal immunoglobulins and complement are deposited at the site of injury in the affected hearts. ${ }^{10}$ The histological lesions reported-partial or complete replacement fibrosis of the atrioventricular node and bundles with a mild generalised myocarditis ${ }^{3}$ are similar to those reported in patients with polymyositis. ${ }^{1}$ A comprehensive recent review of patients with polymyositis emphasised how characteristic the damage to conduction tissue is. ${ }^{2}$ The lesions are related to the length and severity of the disease course but they can progress even when the skeletal muscle inflammation has remitted, and the 
482

patients may die quite unexpectedly. Because cardiac involvement is unrecognised clinically in one third of cases, the identification of a possible serological marker is important.

One of the puzzling features of the anti-Ro seropositive mothers who deliver infants with congential heart block is that their own hearts are apparently unaffected. ${ }^{3}$ In dermatomyositis numerous other immunological abnormalities have been reported ${ }^{4}$ and it may be that these predispose the cases to the pathogenetic effect of the antibody. In our patient, a basic immunoregulatory defect was suggested by the finding of a severe decrease in peripheral blood suppressor lymphocytes and the demonstration of an inflammatory infiltrate including $\mathrm{T}$ and $\mathrm{B}$ lymphocytes and macrophages.

The cause of heart block is unknown in most cases but a minority do have collagen diseases. ${ }^{12}$ The occurrence of anti-Ro antibody in a proportion of patients with collagen disorders ${ }^{3}$ and the presence of high concentrations of heart muscle ${ }^{11}$ are therefore of great importance. We suggest that anti-Ro antibody played a role in producing immunological injury to the heart in our case and that this antibody should be sought in other patients with conduction disorders and connective tissue diseases.

We thank Mrs Catherine Menzies, and Mrs Jan Gairns for technical help and Dr W F Durward and Dr Christine Rodgers for permission to publish this case. This work was supported by the Muscular Dystrophy Group of Great Britain. Access to the fluorescence activated cell sorter was kindly given by Dr HS Micklem, Department of Zoology, Edinburgh University and the Cancer Research Campaign.

\section{References}

1 Askari AO, Huettner TL. Cardiac abnormalities in
Behan, Aitchison, Behan

polymyositis/dermatomyositis. Semin Arthritis Rheum 1982;12:208-19.

2 Stern R, Godbold JH, Chess Q, Kagen LJ. ECG abnormalities in polymyositis. Arch Intern Med 1984; 144:2185-9.

3 Scott JS, Maddison PJ, Taylor PV, Esscher E, Scott O, Skinner RP. Connective-tissue disease, antibodies to ribonucleoprotein, and congenital heart block. $N$ Engl f Med 1983;309:209-12.

4 Behan WMH, Behan PO. Immunological features of polymyositis/dermatomyositis. Springer Seminars in Immunopathology 1985;4:267-93.

5 Davies MJ. Methods of studying the human conduction system. In: Pathology of conducting tissue of the heart. London: Butterworths, 1971:29-37.

6 Bunn CC, Gharavi AE, Hughes GRV. Antibodies to extractable nuclear antigens in 173 patients with DNA-binding positive SLE: an association between antibodies to ribonucleoproteins and $\mathrm{Sm}$ antigens observed by counter-immunoelectrophoresis. $\mathcal{F}$ Clin Lab Immunol 1982;2:13-7.

7 Reinherz EL, Kung PC, Goldstein G, Schlossman SF. A monoclonal antibody with selective reactivity with functionally mature human $T$ cells. $\mathcal{F}$ Immunol 1979;123:1312-7.

8 Behan WMH, Behan PO. Disturbance of regulatory lymphocyte subsets in polymyositis. Ann Neurol 1984;15:112-4.

9 Abdulaziz Z, Mason DY, Stein KC, Gatnner KC, Nash JRG. An immunohistochemical study of the cellular constituents of Hodgkin's disease using a monoclonal antibody panel. Histopathology 1984;8:1-25.

10 Litsey SE, Noonan JA, O'Connor WN, Cottrill CM, Mitchell B. Maternal connective tissue disease and congenital heart block. $N$ Engl f Med 1985;312: 98-100.

11 Davies MJ, Anderson RH, Becker AE. Permanent atrioventricular block. In: The conduction system of the heart. London: Butterworths, 1983:228-51.

12 Wolin SL, Steitz JA. The Ro small cytoplasmic nucleoproteins: identification of the antigenic protein and its binding site on the Ro RNAs. Proc Natl Acad Sci USA 1984;81:1996-2000. 